\title{
A longitudinal study on enteropathogenic infections of livestock in Trinidad
}

\author{
Um estudo longitudinal em infecções enteropathogenic \\ dos animais domésticos em Trinidad
}

\author{
A.A. Adesiyun ${ }^{1 *}$, J.S. Kaminjolo1, M. Ngeleka ${ }^{1}$, A. Mutani', \\ G. Borde ${ }^{1}$, W. Harewood ${ }^{1}$ and W. Harper ${ }^{2}$
}

\begin{abstract}
A longitudinal study was conducted on selected livestock farms to determine the prevalence of enteropathogens in diarrhoeic and non-diarrhoeic animals. The enteropathogens assayed from faecal samples and rectal swabs were bacteria (Escherichia coli, Campylobacter spp. Salmonella spp. and Yersinia enterocolitica), parasites (coccidia, gastrointestinal nematodes and Cryptosporidium spp.) and viruses (group A rotavirus and parvovirus). The prevalence of the enteropathogens in various animal species was related to age and month of the year. Generally, younger animals presented a higher prevalence of infection by enteropathogens than older animals while most infections occurred between the months of January and April. Key-words: Bacteria. Viruses. Parasites. Diarrhea. Livestock.
\end{abstract}

Resumo Um estudo longitudinal foi realizado em fazendas de criação selecionadas, para determinar a prevalência de enteropatógenos em animais com ou sem diarréia. Os enteropatógenos analisados de amostras fecais e swabs retais foram: bactérias (Escherichia coli, Campylobacter spp, Salmonella spp e Yersinia enterocolitica); parasitas (coccídeos, nematóides gastrintestinais e Cryptosporidium spp) e vírus (Rotavírus grupo $A$ e parvovírus). A prevalência dos enteropatógenos em várias espécies de animais foi relacionada à idade e mês do ano. Geralmente, a prevalência de infecção por enteropatógenos foi maior entre os animais mais jovens que entre os animais mais velhos, enquanto a maioria das infecções ocorreu entre os meses de janeiro e abril.

Palavras-chaves: Bactéria. Vírus. Parasitas. Diarrhoea. Criação.

Enteropathogenic viruses, bacteria and parasites are important causative agents of diarrhoeal diseases of livestock world wide ${ }^{1015}$. In Trinidad and Tobago crosssectional studies carried out on various livestock farms have revealed the presence of various bacterial and viral agents $^{14}$. In these studies, farms were visited once and previous diarrhoeal experiences of animals were unknown.
In the present investigation a longitudinal study on selected livestock (cattle, sheep, pigs and goats) was carried out to determine the prevalence of bacterial, parasitic, and viral infections in diarrhoeic and non-diarrhoeic animals over a 12-month period. Age-related prevalence was also investigated.

\section{MATERIAL AND METHODS}

A total of 12 cattle farms, 3 pig farms, 3 sheep and 2 goat farms were studied. Two of the cattle farms also reared sheep. For a period of 12 months all episodes of diarrhea were recorded. At the time of collecting faecal samples from diarrhoeic animals, non-diarrhoeic controls matched for age and sex were also sampled, whenever possible.
To detect Escherichia coli, Salmonella, Yersinia and Campylobacter the procedure used was that described by Adesiyun et $\mathrm{al}^{4}$. Cryptosporidium was detected using the method of Garcia et $\mathrm{al}^{9}$ while the method of Long ${ }^{13}$ was employed to detect coccidia. Gastrointestinal nematodes were detected by the floatation technique as described by Thienpont et $\mathrm{al}^{18}$. Group A rotavirus was

\footnotetext{
1. School of Veterinary Medicine, Faculty of Medical Sciences, The University of the West Indies, St. Augustine, Trinidad; 2. Ministry of Agriculture, Land and Marine Resources, Port of Spain, Trinidad.

Address to: Dr. A.A. Adesiyun. School of Veterinary Medicine/Faculty of Medical Sciences/The University of the West Indies, St. Augustine. Trinidad and Tobago.

Fax/Phone: 1-868-645-7428

E-mail: abiodun@tstt.net

Recebido para publicação em 10/3/2000.
} 
detected using the Rota Screen Kit (Mercia Diagnostics, U.K). Parvovirus was detected following the method of Carmichael et $\mathrm{al}^{7}$ and all positive samples were confirmed by the haemagglutination - inhibition test as described previously ${ }^{11}$ using specific negative and positive parvovirus antiserum (National Vet Services Lab, USA).
Statistical analysis of data for differences in prevalence between diarrhoeic and non-diarrhoeic animals and differences related to age and month of the year were carried out using the chi-square test for independence.

\section{RESULTS}

The prevalence of E. coli, Campylobacter spp and Salmonella spp in diarrhoeic and non-diarrhoeic animals is shown in Table 1. Out of 188 diarrhoeic animals (cattle, pig, sheep and goats) sampled, 140 (74.5\%), 54 (28.7\%), $5(2.7 \%)$ and $0(0 \%)$ yielded E. coli, Campylobacter, Salmonella and $Y$. enterocolitica respectively, while the corresponding prevalence for 174 non-diarrhoeic animals was $119(68.4 \%), 42(24.1 \%), 4(2.3 \%)$ and $0(0.0 \%)$, respectively. The difference was not statistically significant $\left(p>0.05 ; \chi^{2}\right)$. In cattle and pigs, the frequencies of detecting the enteropathogens were higher in diarrhoeic than in non-diarrhoeic animals but these differences were not statistically significant $(p>0.05$; $\left.\chi^{2}\right)$. All samples were negative for $Y$. enterocolitica.

Table 1 - Prevalence of E. coli, Campylobacter spp., and Salmonella spp. in the animals studied.

\begin{tabular}{|c|c|c|c|c|c|}
\hline \multirow[b]{2}{*}{ Animal species } & \multirow[b]{2}{*}{ Status $^{a}$} & \multirow[b]{2}{*}{ № of samples } & \multicolumn{3}{|c|}{ № (\%) positive ${ }^{b}$ for: } \\
\hline & & & E. coli & Campylobacter spp & Salmonella spp \\
\hline \multirow[t]{2}{*}{ Bovine } & $\mathrm{D}$ & 41 & 35 (85.3) & $11(26.8)$ & $2(4.8)$ \\
\hline & ND & 33 & $26(78.7)$ & $4(12.1)$ & $1(3.0)$ \\
\hline \multirow[t]{2}{*}{ Porcine } & $\mathrm{D}$ & 138 & $96(69.5)$ & $43(31.2)$ & $3(2.2)$ \\
\hline & ND & 132 & $84(63.6)$ & $37(28.0)$ & $3(2.2)$ \\
\hline \multirow[t]{2}{*}{ Ovine } & $\mathrm{D}$ & 4 & $4(100.0)$ & $0(0.0)$ & $0(0.0)$ \\
\hline & ND & 4 & $4(100.0)$ & $1(25.0)$ & $0(0.0)$ \\
\hline \multirow[t]{2}{*}{ Caprine } & D & 5 & $5(100.0)$ & $0(0.0)$ & $0(0.0)$ \\
\hline & ND & 5 & $5(100.0)$ & $0(0.0)$ & $0(0.0)$ \\
\hline
\end{tabular}

D: Diarrhoeic; ND: Non-diarrhoeic

${ }^{\mathrm{b}}$ All samples cultured were negative for $Y$. enterocolitica

Table 2 shows the monthly prevalence of $E$. coli, Campylobacter spp and Salmonella spp in the cattle tested. For all pathogens, most detections were made in the months of January, February, March and April but the differences in prevalence were not statistically significant $\left(p>0.05 ; \chi^{2}\right)$.

Table 2 - Monthly prevalences of E. coli, Campylobacter spp, and Salmonella spp in cattle.

\begin{tabular}{|c|c|c|c|c|c|c|c|c|c|c|}
\hline \multirow[b]{2}{*}{ Microorganism } & \multirow[b]{2}{*}{ Status $^{a}$} & \multicolumn{9}{|c|}{ № $(\%)$ of samples positive for the months ${ }^{\mathrm{b}}$ of: } \\
\hline & & $\mathrm{J}$ & $\mathrm{F}$ & M & A & M & $\mathrm{Jn}$ & $\mathrm{J}$ & A & $S$ \\
\hline \multirow[t]{2}{*}{ E. coli } & $\mathrm{D}$ & $9(64.2)$ & $8(100.0)$ & $8(100.0)$ & $4(100.0)$ & $0(0.0)$ & $0(0.0)$ & $1(100.0)$ & $3(100.0)$ & $2(100.0)$ \\
\hline & ND & $3(42.8)$ & $7(87.5)$ & $6(85.7)$ & $3(75.0)$ & $0(0.0)$ & $1(100.0)$ & $1(100.0)$ & $3(100.0)$ & $2(100.0)$ \\
\hline \multirow[t]{2}{*}{ Campylobacter spp } & D & $5(35.7)$ & $3(37.5)$ & $0(0.0)$ & $0(0.0)$ & $0(0.0)$ & $1(100.0)$ & $0(0.0)$ & $1(33.3)$ & $1(50.0)$ \\
\hline & ND & $0(0.0)$ & $1(12.5)$ & $0(0.0)$ & $0(0.0)$ & $0(0.0)$ & $1(100.0)$ & $0(0.0)$ & $2(66.6)$ & $0(0.0)$ \\
\hline \multirow[t]{2}{*}{ Salmonella spp } & $\mathrm{D}$ & $0(0.0)$ & $0(0.0)$ & $2(25.0)$ & $0(0.0)$ & $0(0.0)$ & $0(0.0)$ & $0(0.0)$ & $0(0.0)$ & $0(0.0)$ \\
\hline & ND & $1(14.2)$ & $0(0.0)$ & $0(0.0)$ & $0(0.0)$ & $0(0.0)$ & $0(0.0)$ & $0(0.0)$ & $0(0.0)$ & $0(0.0)$ \\
\hline \multirow{2}{*}{$\begin{array}{l}\text { Total } n^{\circ} \text { of } \\
\quad \text { samples tested }\end{array}$} & $\mathrm{D}$ & 14 & 8 & 8 & 4 & 0 & 1 & 1 & 3 & 2 \\
\hline & ND & 7 & 8 & 7 & 4 & 0 & 1 & 1 & 3 & 2 \\
\hline
\end{tabular}

a: Diarrhoeic; ND: Non-diarrhoeic

${ }^{b}$ No samples were received in October, November and December

The monthly prevalence of E. coli, Campylobacterand Salmonella in pigs is shown in Table 3. E. coli was isolated throughout the study period except in January and December when no sample was tested. Campylobacter was isolated from pigs between February and July while Salmonella was detected in February, April and October. The monthly prevalence of each pathogen in diarrhoeic and non-diarrhoeic animals was not significantly different $(p$ $\left.>0.05 ; \chi^{2}\right)$.

The age-group-specific prevalence of $E$. coli, Campylobacter and Salmonella in cattle is shown in 
Table 3 - Monthly prevalence of E. coli, Campylobacter spp, and Salmonella spp in pigs.

\begin{tabular}{lcccccccccccc}
\hline & & \multicolumn{10}{c}{ № (\%) of samples positive for the months ${ }^{\mathrm{b}}$ of: } \\
\cline { 3 - 13 } Microorganism & Status $^{\mathrm{a}}$ & $\mathrm{F}$ & $\mathrm{M}$ & $\mathrm{A}$ & $\mathrm{M}$ & $\mathrm{Jn}$ & $\mathrm{J}$ & $\mathrm{A}$ & $\mathrm{S}$ & $\mathrm{O}$ & $\mathrm{N}$ \\
\hline E. coli & $\mathrm{D}$ & $7(70.0)$ & $14(70.0)$ & $18(66.6)$ & $14(60.8)$ & $11(57.8)$ & $15(83.3)$ & $2(100.0)$ & $6(100.0)$ & $4(66.6)$ & $5(71.4)$ \\
& $\mathrm{ND}$ & $6(60.0)$ & $10(83.3)$ & $12(41.3)$ & $15(65.2)$ & $14(73.6)$ & $12(66.6)$ & $2(100.0)$ & $3(50.0)$ & $6(100.0)$ & $4(57.1)$ \\
Campylobacter spp & $\mathrm{D}$ & $4(40.0)$ & $9(45.0)$ & $14(51.8)$ & $2(8.6)$ & $10(52.6)$ & $4(22.2)$ & $0(0.0)$ & $0(0.0)$ & $0(0.0)$ & $0(0.0)$ \\
& $\mathrm{ND}$ & $3(30.0)$ & $3(25.0)$ & $11(37.9)$ & $5(21.7)$ & $11(57.8)$ & $4(22.2)$ & $0(0.0)$ & $0(0.0)$ & $0(0.0)$ & $0(0.0)$ \\
Salmonella spp & $\mathrm{D}$ & $2(20.0)$ & $0(0.0)$ & $1(3.7)$ & $0(0.0)$ & $0(0.0)$ & $0(0.0)$ & $0(0.0)$ & $0(0.0)$ & $0(0.0)$ & $0(0.0)$ \\
& $\mathrm{ND}$ & $1(10.0)$ & $0(0.0)$ & $0(0.0)$ & $0(0.0)$ & $0(0.0)$ & $0(0.0)$ & $0(0.0)$ & $0(0.0)$ & $2(33.3)$ & $0(0.0)$ \\
\hline Total no of & $\mathrm{D}$ & 10 & 20 & 27 & 23 & 19 & 18 & 2 & 6 & 6 & 7 \\
samples tested & $\mathrm{ND}$ & 10 & 12 & 29 & 23 & 19 & 18 & 2 & 6 & 6 & 7 \\
\hline
\end{tabular}

aD: Diarrhoeic; ND: Non-diarrhoeic

${ }^{b}$ No samples were received in January and December

Table 4. Of a total of 41 diarrhoeic cattle reported during the study period, $32(78 \%)$ belonged to the $0-3$ month age group, which was significantly higher than the other groups $\left(p<0.05 ; \chi^{2}\right)$. The presence of $E$. coli in faecal or rectal swab samples was relatively high in all age groups tested, $84.3 \%$ to $100 \%$, Campylobacter prevalence rates increased with age from $18.2 \%$ in the $0-3$ month age group to $36.4 \%$ in the $>3-6$ month age group and in the 0-3 month age group. The prevalence of Salmonella infection was $3.6 \%$ compared to $0.0 \%$ found in the $>3-6$ month age group. For all age groups, the prevalence of the enteropathogens tested for was generally higher in diarrhoeic cattle than in non-diarrhoeic cattle but the differences were not statistically significant $\left(p>0.05 ; \chi^{2}\right)$.

Table 5 shows the age-related prevalence of $E$. coli, Campylobacter and Salmonella infections in pigs. Of a total of 138 diarrhoeic pigs studied, 99 (71.7\%) belonged to the $0-1$ week age group and the differences compared with other age groups were highly significant $(p<0.05$; $\chi^{2}$ ). In pigs in the $0-1,>1-4,>4-8$ week age groups, the prevalence of each of the three pathogens was higher in diarrhoeic pigs than in non-diarrhoeic pigs.

Table 4 - Age group specific prevalence of E. coli, Campylobacter spp and Salmonella spp in cattle.

\begin{tabular}{|c|c|c|c|c|c|}
\hline \multirow[b]{2}{*}{ Age (months) } & \multirow[b]{2}{*}{ Status $^{a}$} & \multirow[b]{2}{*}{ № of samples } & \multicolumn{3}{|c|}{ № (\%) positive for: } \\
\hline & & & E. coli & Campylobacter spp & Salmonella spp \\
\hline \multirow[t]{2}{*}{$0-3$} & $\mathrm{D}$ & 32 & $27(84.3)$ & $9(28.1)$ & $1(3.1)$ \\
\hline & ND & 23 & $17(73.9)$ & $1(4.3)$ & $1(4.3)$ \\
\hline \multirow[t]{2}{*}{$>3-6$} & D & 6 & $5(83.3)$ & $1(16.6)$ & $0(0.0)$ \\
\hline & ND & 5 & $4(80.0)$ & $3(60.0)$ & $0(0.0)$ \\
\hline \multirow[t]{2}{*}{$>6$} & $\mathrm{D}$ & 3 & $3(100.0)$ & $1(33.3)$ & $1(33.3)$ \\
\hline & ND & 5 & $5(100.0)$ & $0(0.0)$ & $0(0.0)$ \\
\hline
\end{tabular}

aD: Diarrhoeic; ND: Non-diarrhoeic

Table 5 - Age group specific prevalence of E. coli, Campylobacter spp, Salmonella spp in pigs.

\begin{tabular}{|c|c|c|c|c|c|}
\hline \multirow[b]{2}{*}{ Age (weeks) } & \multirow[b]{2}{*}{ Status $^{a}$} & \multirow[b]{2}{*}{ № of samples } & \multicolumn{3}{|c|}{ № (\%) positive for: } \\
\hline & & & E. coli & Campylobacter spp & Salmonella spp \\
\hline \multirow[t]{2}{*}{$0-1$} & $\mathrm{D}$ & 99 & $67(67.6)$ & $16(16.1)$ & $0(0.0)$ \\
\hline & ND & 94 & $56(59.5)$ & $13(13.8)$ & $0(0.0)$ \\
\hline \multirow[t]{2}{*}{$>1-4$} & D & 12 & 10 (83.3) & $9(75.0)$ & $0(0.0)$ \\
\hline & ND & 12 & $8(66.6)$ & $11(91.6)$ & $0(0.0)$ \\
\hline \multirow[t]{2}{*}{$>4-8$} & $\mathrm{D}$ & 19 & $16(84.2)$ & $12(63.1)$ & $3(15.7)$ \\
\hline & ND & 22 & $17(77.2)$ & $10(45.4)$ & $1(4.5)$ \\
\hline \multirow[t]{2}{*}{$>8$} & D & 8 & $3(37.5)$ & $6(75.0)$ & $0(0.0)$ \\
\hline & ND & 4 & $3(75.0)$ & $3(75.0)$ & $2(50.0)$ \\
\hline
\end{tabular}

${ }^{a} \mathrm{D}$ : Diarrhoeic; ND: Non-diarrhoeic 
The exception was the prevalence of Campylobacter in the $>1-4$ week age group where the reverse was observed. For the various age groups, the lowest prevalence of E. coli, $63.7 \%$ (123 out of 193); Campylobacter, $15 \%$ (29 out of 193) and Salmonella, 0\% (0 out of 193) were found in the 0-1 week age group. The highest prevalence enteropathogens found in the various age groups were: $33(80.5 \%)$ out of 41 for $E$. coli in the $>4-8$ week age group, $20(83.3 \%)$ out of 24 Campylobacter in the $>1-4$ week age group and for Salmonella, $2(16.7 \%)$ out of 12 in the over 8 weeks age group. Overall, the differences in isolation rates of the enteropathogens in diarrhoeic and non-diarrhoeic pigs were however not statistically significant $\left(p>0.05 ; \chi^{2}\right)$.

The prevalence of viruses and gastrointestinal parasites are shown in Table 6. Rotavirus was most prevalent in cattle, with 11 (18.6\%) out of 59 animals being positive. Rotavirus was detected at a higher frequency, $21.9 \%$ (7 out of 32 ) in diarrhoeic cattle compared to a rate of $14.8 \%$ (4 out of 27) found in non-diarrhoeic cattle but the difference was not statistically significant $\left(p>0.05 ; \chi^{2}\right)$.

Table 6 - Prevalence of gastrointestinal parasites and viruses in animals studied.

\begin{tabular}{|c|c|c|c|c|c|c|c|c|c|}
\hline \multirow[b]{3}{*}{$\begin{array}{l}\text { Animal } \\
\text { species }\end{array}$} & \multirow[b]{3}{*}{ Status $^{a}$} & \multirow[b]{3}{*}{$\begin{array}{c}\text { № of } \\
\text { samples }\end{array}$} & \multicolumn{7}{|c|}{ № (\%) positive for: } \\
\hline & & & \multicolumn{5}{|c|}{ Parasites } & \multicolumn{2}{|c|}{ Viruses } \\
\hline & & & Coccidia & $\mathrm{GIN}^{\mathrm{b}}$ & $\begin{array}{c}\text { № of } \\
\text { samples }\end{array}$ & Cryptosporidium & $\begin{array}{c}\text { № of } \\
\text { samples }\end{array}$ & $\operatorname{Rota}^{c}$ & Parvo $^{d}$ \\
\hline \multirow[t]{2}{*}{ Bovine } & $\mathrm{D}$ & 18 & $3(16.7)$ & $3(16.7)$ & 32 & $3(9.4)$ & 32 & $8(25.0)$ & $12(37.5)$ \\
\hline & ND & 17 & $2(11.8)$ & $5(27.8)$ & 27 & $1(3.7)$ & 27 & $2(7.4)$ & 7 (25.9) \\
\hline \multirow[t]{2}{*}{ Porcine } & $\mathrm{D}$ & 23 & $0(0.0)$ & $0(0.0)$ & 26 & $0(0.0)$ & 26 & $0(0.0)$ & $5(19.2)$ \\
\hline & ND & 24 & $0(0.0)$ & $0(0.0)$ & 26 & $1(3.8)$ & 26 & $0(0.0)$ & $4(15.4)$ \\
\hline \multirow[t]{2}{*}{ Ovine } & $\mathrm{D}$ & 5 & $0(0.0)$ & $1(20.0)$ & 2 & $0(0.0)$ & 2 & $1(50.0)$ & $0(0.0)$ \\
\hline & ND & 5 & $0(0.0)$ & $1(20.0)$ & 2 & $0(0.0)$ & 2 & $0(0.0)$ & $0(0.0)$ \\
\hline
\end{tabular}

${ }^{a}$ D: Diarrhoeic; ND: Non-diarrhoeic

bGIN: gastrointestinal nematodes

cRota: Rotavirus

dParvo: Parvovirus

Parvovirus was detected in 27 (23.5\%) out of a total of 115 animals tested with no positive samples found in sheep. In cattle, parvovirus was detected in 11 (34.4\%) out of 32 diarrhoeic animals but only in $7(25.9 \%)$ out of 27 non-diarrhoeic animals. In pigs, 5 (19.2) out of 26 diarrhoeic animals sampled yielded parvovirus while 4 (15.4\%) out of 26 non-diarrhoeic pigs were positive. The difference in infection rates by parvovirus between diarrhoeic and non-diarrhoeic cattle and pigs were, however, not statistically significant $\left(p>0.05 ; \chi^{2}\right)$. From the same samples, $4(6.8 \%)$ yielded Cryptosporidium, with $3(9.4 \%)$ out of 32 and $1(3.7 \%)$ out of 27 cattle positive among diarrhoeic and non-diarrhoeic cattle, respectively. A total of 52 pigs were tested and only $1(1.9 \%)$ yielded Cryptosporidium.

Coccidia were detected in cattle only, with $3(8.6 \%)$ out of 35 herds of cattle being positive. Only $2(11.8 \%)$ out of 17 diarrhoeic cattle yielded coccidia, compared to 1 (5.5\%) out of 18 non-diarrhoeic cattle. Gastrointestinal nematodes were detected in cattle and sheep with prevalence of $22.9 \%$ ( 8 out of 35 ) and $20 \%$ ( 2 out of 10 ), respectively. The differences were not statistically significant $\left(p>0.05 ; \chi^{2}\right)$.
Overall, the prevalence of infection in the three animal species studied for viruses were 10.4\% (12 out of 115 ) for rotavirus and $23.5 \%$ (27 out of 115 ) for parvovirus, $4.3 \%$ (5 out of 115) for Cryptosporidium, 3.3\% (3 out of 92) for coccidia, and $10.9 \%$ (10 out of 92 ) for gastrointestinal nematodes.

Table 7 shows the monthly prevalence of infection by viruses and gastrointestinal parasites in cattle. These enteropathogens were most prevalent in the months of January, February and March.

The age-group-specific prevalence for each virus and gastrointestinal parasite in cattle tested is shown in Table 8. The 0-3 month age group has the highest prevalence compared with the $>3-6$ and $>6$ months age groups for rotavirus (20.4\%), parvovirus (34.7\%), Cryptosporidium $(8.2 \%)$, coccidia (10\%), gastrointestinal nematodes (23.3\%). Regardless of the age groups, the differences in prevalence of infections by viruses and gastrointestinal parasites between diarrhoeic and non-diarrhoeic animals were not statistically significant $\left(p>0.05 ; \chi^{2}\right)$. 
Table 7 - Monthly prevalence of various gastrointestinal parasites and viruses in cattle.

\begin{tabular}{|c|c|c|c|c|c|c|c|c|c|}
\hline \multirow[b]{2}{*}{ Microorganism } & \multirow[b]{2}{*}{ Status ${ }^{a}$} & \multicolumn{8}{|c|}{ № (\%) positive for the months ${ }^{b}$ of: } \\
\hline & & $\mathrm{J}$ & $\mathrm{F}$ & $\mathrm{M}$ & $\mathrm{A}$ & $\mathrm{M}$ & $\mathrm{Jn}$ & $\mathrm{A}$ & $\mathrm{S}$ \\
\hline \multirow[t]{2}{*}{ Coccidia } & $\mathrm{D}$ & $0(0.0)$ & $1(12.5)$ & $0(0.0)$ & $0(0.0)$ & $0(0.0)$ & $0(0.0)$ & $0(0.0)$ & $0(0.0)$ \\
\hline & ND & $0(0.0)$ & $1(12.5)$ & $1(7.7)$ & $0(0.0)$ & $0(0.0)$ & $0(0.0)$ & $0(0.0)$ & $0(0.0)$ \\
\hline \multirow[t]{2}{*}{ GINc } & $\mathrm{D}$ & $0(0.0)$ & $1(12.5)$ & $2(15.4)$ & $0(0.0)$ & $0(0.0)$ & $0(0.0)$ & $0(0.0)$ & $0(0.0)$ \\
\hline & ND & $0(0.0)$ & $1(12.5)$ & $3(23.0)$ & $0(0.0)$ & $0(0.0)$ & $0(0.0)$ & $0(0.0)$ & $0(0.0)$ \\
\hline \multirow[t]{2}{*}{ Cryptosporidium } & $\mathrm{D}$ & $3(33.3)$ & $0(0.0)$ & $0(0.0)$ & $0(0.0)$ & $0(0.0)$ & $0(0.0)$ & $0(0.0)$ & $0(0.0)$ \\
\hline & ND & $1(14.7)$ & $0(0.0)$ & $0(0.0)$ & $0(0.0)$ & $0(0.0)$ & $0(0.0)$ & $0(0.0)$ & $0(0.0)$ \\
\hline \multirow[t]{2}{*}{ Rotavirus } & D & $3(33.3)$ & $3(42.9)$ & $1(12.5)$ & $0(0.0)$ & $0(0.0)$ & $0(0.0)$ & $0(0.0)$ & $0(0.0)$ \\
\hline & ND & $1(14.7)$ & $2(40.0)$ & $0(0.0)$ & $1(33.3)$ & $0(0.0)$ & $0(0.0)$ & $0(0.0)$ & $0(0.0)$ \\
\hline \multirow[t]{3}{*}{ Parvovirus } & $\mathrm{D}$ & $3(33.3)$ & $1(14.3)$ & $5(62.5)$ & $0(0.0)$ & $0(0.0)$ & $1(100.0)$ & $1(33.3)$ & $0(0.0)$ \\
\hline & ND & $0(0.0)$ & $1(20.0)$ & $4(57.1)$ & $0(0.0)$ & $0(0.0)$ & $1(100.0)$ & $1(33.3)$ & $0(0.0)$ \\
\hline & & \multicolumn{8}{|c|}{ Total no of samples tested } \\
\hline \multirow[t]{2}{*}{ Parasites } & $\mathrm{D}$ & 0 & 8 & 13 & 5 & 0 & 0 & 0 & 2 \\
\hline & ND & 0 & 7 & 13 & 5 & 0 & 0 & 0 & 2 \\
\hline \multirow[t]{2}{*}{ Cryptosporidium } & D & 9 & 7 & 8 & 2 & 0 & 0 & 0 & 0 \\
\hline & ND & 7 & 5 & 7 & 3 & 0 & 0 & 0 & 0 \\
\hline \multirow[t]{2}{*}{ Viruses } & D & 9 & 7 & 8 & 2 & 0 & 1 & 3 & 0 \\
\hline & ND & 7 & 5 & 7 & 3 & 0 & 1 & 3 & 0 \\
\hline
\end{tabular}

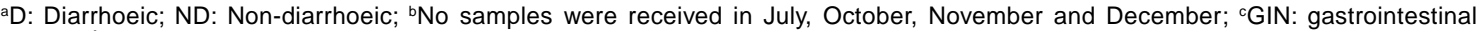
nematodes

Table 8 - Age group specific of gastrointestinal parasites and viruses in cattle.

\begin{tabular}{|c|c|c|c|c|c|c|c|c|c|}
\hline \multirow[b]{3}{*}{ Age (months) } & \multirow[b]{3}{*}{ Status $^{a}$} & \multicolumn{8}{|c|}{ № (\%) positive for: } \\
\hline & & \multicolumn{5}{|c|}{ Parasites } & \multicolumn{3}{|c|}{ Viruses $^{d}$} \\
\hline & & № of samples & Coccidia & Gin $^{b}$ & № of samples & Crypto $^{c}$ & № of samples & Rota & Parvo \\
\hline \multirow[t]{2}{*}{$\overline{0-3}$} & $\mathrm{D}$ & 16 & $2(12.5)$ & $3(18.8)$ & 28 & $3(10.7)$ & 28 & $8(28.5)$ & $11(39.3)$ \\
\hline & ND & 14 & $1(7.0)$ & $4(28.6)$ & 21 & $1(4.8)$ & 21 & $2(9.5)$ & $5(23.8)$ \\
\hline \multirow[t]{2}{*}{$>3-6$} & D & 0 & $0(0.0)$ & $0(0.0)$ & 0 & $0(0.0)$ & 0 & $0(0.0)$ & $0(0.0)$ \\
\hline & ND & 1 & $0(0.0)$ & $0(0.0)$ & 4 & $0(0.0)$ & 4 & $0(0.0)$ & $1(25.0)$ \\
\hline \multirow[t]{2}{*}{$>6$} & D & 2 & $0(0.0)$ & $0(0.0)$ & 4 & $0(0.0)$ & 4 & $0(0.0)$ & $1(25.0)$ \\
\hline & ND & 2 & $0(0.0)$ & $1(50.0)$ & 2 & $0(0.0)$ & 2 & $1(50.0)$ & $0(0.0)$ \\
\hline
\end{tabular}

aD: Diarrhoeic; ND: Non-diarrhoeic; ${ }^{b} \mathrm{GIN}$ : gastrointestinal nematodes; ${ }^{\mathrm{c} C r y p t o}$ - Cryptosporidium spp; ${ }^{\mathrm{d}}$ Rota: Rotavirus; Parvo: Parvovirus

\section{DISCUSSION}

It is well documented that all the enteropathogens involved in the present investigation are aetiological agents of diarrhea in animals ${ }^{19}$ and man ${ }^{20}$. Diarrhoeic animals of all species were found to have a higher prevalence of all infections than non-diarrhoeic animals, although these differences were not significant. Failure to demonstrate a direct association between the presence of enteropathogens and diarrhea has been reported previously ${ }^{38}$.

The finding that a slightly higher prevalence of infection with Campylobacter was found in diarrhoeic $(28.7 \%)$ compared with non-diarrhoeic animals $(24.1 \%)$ is in agreement with results of previous workers ${ }^{14}{ }^{16}$. Campylobacter is known to be an important cause of gastroenteritis in livestock ${ }^{17}$. However, several factors could be attributed to a failure to detect a significant association of microorganism with diarrhea in animals as shown by Adesiyun et al ${ }^{1}$.

For some unexplained reason the overall prevalence of Salmonella was low in both diarrhoeic and nondiarrhoeic animals. Similar findings have been reported ${ }^{8}$.
Failure to isolate $Y$. enterocolitica from the livestock tested may be a reflection of non-exposure of the animals to the microorganism on the farms sampled. It is known that in tropical environments such as Trinidad and Tobago, rates of infections by $Y$. enterocolitica are relatively low as reported by Adesiyun et al ${ }^{2}$.

Although $E$. coli, a normal flora of the gastrointestinal tracts of animals and humans, was detected with a high frequency in both diarrhoeic and non-diarrhoeic livestock, its true pathogenic significance cannot be ascertained from the present results. This would require the determination of the serotypes, virulence and pathogenicity of the isolates.

In an earlier study on several enteropathogens, Adesiyun and Kaminjolo ${ }^{3}$ reported that only rotavirus was detected at a statistically significantly higher frequency in diarrhoeic compared with non-diarrhoeic cattle, pigs and sheep in Trinidad. The present longitudinal study shows that there were no significant differences between the prevalence of rotavirus in diarrhoeic and non-diarrhoeic animals. The differences in the results of the two studies may be attributed to the following factors: in the present study, 367 samples 
were used as compared to 693 samples used in the previous study; the present study involved 19 farms as compared with 50 farms used previously ${ }^{3}$; and finally, the two study designs were different. Reports elsewhere have shown that rotavirus is a major cause of gastroenteritis in newborn animals ${ }^{6}$. In the present study, rotavirus infection was found to be highest in calves aged 0-3 weeks, a finding that is in agreement with those of Brenner et $\mathrm{al}^{6}$ and De Rycke et $\mathrm{al}^{8}$.

The presence of parvovirus in livestock in Trinidad and Tobago is being reported here for the first time. The fact that nearly a quarter of the animals tested, both diarrhoeic and non-diarrhoeic, were positive for this agent suggests that it is widespread in the livestock population. The finding of a higher frequency of detection of parvovirus in diarrhoeic cattle and pigs compared with non-diarrhoeic animals suggests some aetiological importance, although the differences were not statistically different. Studies elsewhere have reported comparable prevalence of infection by parvovirus in livestock ${ }^{5}$.

Cryptosporidium, a known causative agent of gastroenteritis in livestock and first reported in livestock in Trinidad by Kaminjolo et $\mathrm{al}^{12}$ was also detected in cattle and pigs in this study with $4(6.8 \%)$ out of 59 and $1(1.9 \%)$ out of 52 positive animals, respectively. As found with other enteropathogens, the corresponding prevalence of infection with Cryptosporidium in an earlier study was higher with $8.7 \%$ (26 of out 298 ) in cattle and $19.6 \%$ (54 out of 275 ) in pigs respectively ${ }^{12}$. The relatively low infection rates by coccidia and gastrointestinal helminths may reflect the deworming programs practiced by the farmers.

Regardless of animal species and types of enteropathogens assayed for, age appeared to be a significant factor in the occurrence of diarrhea. Young animals experienced diarrhea more frequently than older animals. The prevalence of infections by enteropathogens was also higher among the young than in older animals. It is well established that morbidity and mortality due to enteropathogens are most prevalent in this age group ${ }^{6}{ }^{19}$.

Based on the data from the present study, it appears that most of the diarrhoeal episodes were reported in the first quarter of the year (January to April), a period which had a corresponding increase in the detection of enteropathogens in the livestock sampled.

In conclusion, rotavirus appears to be the most important enteropathogen among those investigated. The fact that all other enteropathogens looked for had a higher prevalence of infection in diarrhoeic compared with non-diarrhoeic livestock also suggests aetiological significance though possibly obscured by confounding factors.

\section{ACKNOWLEDGMENTS}

We wish to acknowledge the assistance of the staff of the Veterinary Services Unit of the Ministry of Agriculture, Land and Marine Affairs. Mr. G. Ramirez, Ms. N. Seepersadsingh, Mrs. S. Uddenberg \& Mrs. T. Niles-Pierre are thanked for their technical help and Mrs. Liza Garraway for typing the manuscript. The University of the West Indies, St. Augustine Campus Research and Publications Committee is acknowledged for financial support.

\section{REFERENCES}

1. Adesiyun AA, Kaminjolo JS. Prevalence and epidemiology of selected enteric infections of livestock in Trinidad. Preventive Veterinary Medicine 19: 151 - 165, 1994.

2. Adesiyun AA, Kaminjolo JS, Loregnard R, Kitson-Piggot W. Campylobacter infections in calves, piglets, lambs and kids in Trinidad. British Veterinary Journal 148: 547 - 556, 1992a.

3. Adesiyun AA, Kaminjolo JS, Loregnard R, Kitson-Piggot W. Frequency of isolation of Yersinia enterocolitica from livestock in Trinidad. The Veterinary Record 131: 516, 1992b.

4. Adesiyun AA, Webb LA, Romain H, Kaminjolo JS. Prevalence of Salmonella, Listeria monocytogenes, Campylobacter spp., Yersinia enterocolitica and Cryptosporidium spp. in bulk milk, cows faeces and effluents of dairy farms. Revue d'Elevage et de Medicine Veterinaire des Pays Tropicaux 49: 303 - 309, 1996.

5. Barnes MA, Wright E, Bodine AB, Alberty CF. Frequency of bluetongue and bovine parvovirus infections in cattle in South Carolina dairy herds. American Journal of Veterinary Research 43:1078-1080, 1982.

6. Brennder J, Elad D, Markovics A, Grinberg A, Trainin Z. Epidemiological study on neonatal calf diarrhoea in Isreal-a oneyear survey of faecal samples. Israel Journal of Veterinary Medicine 48: 113 - 116, 1993
7. Carmichael LE, Joubert JC, Pollock RVH. Haemagglutination by canine parvovirus: serological studies and diagnostic applications. American Journal of Veterinary Research 41: 784 - 791, 1980.

8. De Rycke J, Bernard S, Laporte J, Naciri M, Popoff MR, Rodlakis A. Prevalence of various enteropathogens in the faeces of diarrhoeic and healthy calves. Annales Recherches Veterinaires 17: 159 - 168, 1986.

9. Garcia LS, Bruckner DA, Brewer TC, Shimizu RY. Techniques for the recovery and identification of Cryptosporidium oocysts from stool specimens. Journal of Clinical Microbiology 18: 185 - 190, 1983.

10. Holland RE. Some infectious causes of diarrhoea in young farm animals. Clinical Microbiological Reviews 3: 345 - 375, 1990.

11. Joo HS, Donaldson-Wood CR, Johnson RH. A standardized haemagglutination inhibition test for porcine parvovirus antibody. AustralianVeterinary Journal 52: 422 - 424, 1976.

12. Kaminjolo JS, Adesiyun AA, Loregnard R, Kitson-Piggot W. Prevalence of Cryptosporidium oocysts in livestock in Trinidad and Tobago. Veterinary Parasitology 45: 209 - 213, 1993.

13. Long P. Coccidiosis in man and domestic animals. CRC Press, Boca Raton, Florida, 1990.

14. Manser PA, Dalzier RW. A survey of Campylobacter in animals. Journal of Hygiene 95:15-21, 1985. 
15. Pohjola S, Oksanen H, Neuronen E, Veijaiainen P, Kenriksson K. Certain enteropathogens in calves in Finnish dairy herds with recurrent outbreak of diarrhoea. Preventive Veterinary Medicine. 3: 547 - 558, 1986.

16. Prescott JF, Bruin-Mosch CW. Carriage of Campylobacter jejuni in healthy and diarrhoeic animals. American Journal of Veterinary Research 42: 164 - 165, 1981.

17. Supar-Hurst RG, Pattern BE. The importance of enterotoxigenic Escherichia coli containing the $987 \mathrm{P}$ antigen in causing neonatal colibacillosis in piglets in Indonesia. Veterinary Microbiology 26: $393-400,1991$.
18. Thienport D, Rochette F, Vanparys OF. Diagnosing Helminthiasis by Coprological Examination. $2^{\text {nd }}$ ed. Jansen Research Foundation, Beerse. 1986.

19. Tzipori S. The relative importance of enteric pathogens affecting neonates of domestic animals. Advances in Veterinary Science and Comparative Medicine. 29: 103 - 206.

20. Urquhart GM, Armour J, Duncan JL, Dunn AM, Jennings FW. Veterinary Parasitology, $3^{\text {rd }}$ ed. Longman. London. 1987. 